July 1985

\title{
Psychotherapy or Pseudotherapy?
}

Lawson R. Wulsin, MD

Thomas Jefferson University Hospital

Follow this and additional works at: https://jdc.jefferson.edu/jeffjpsychiatry

Part of the Psychiatry Commons

Let us know how access to this document benefits you

\section{Recommended Citation}

Wulsin, MD, Lawson R. (1985) "Psychotherapy or Pseudotherapy?," Jefferson Journal of Psychiatry. Vol. 3 : Iss. 2 , Article 10.

DOI: https://doi.org/10.29046/JJP.003.2.009

Available at: https://jdc.jefferson.edu/jeffjpsychiatry/vol3/iss2/10

This Article is brought to you for free and open access by the Jefferson Digital Commons. The Jefferson Digital Commons is a service of Thomas Jefferson University's Center for Teaching and Learning (CTL). The Commons is a showcase for Jefferson books and journals, peer-reviewed scholarly publications, unique historical collections from the University archives, and teaching tools. The Jefferson Digital Commons allows researchers and interested readers anywhere in the world to learn about and keep up to date with Jefferson scholarship. This article has been accepted for inclusion in Jefferson Journal of Psychiatry by an authorized administrator of the Jefferson Digital Commons. For more information, please contact: JeffersonDigitalCommons@jefferson.edu. 
to a blanket as a symbol of his mother's love, C. could use her knitting to endure leaving the safety of the hospital environment. She could then continue her projects at home; they would be constant reminders of the hospital and her therapist.

Learning to knit may be seen as a metaphor for C.'s recovery. Like a snail peeking out from its shell, C. tentatively began to interact with me. Her knitting was at first full of holes and clumsily executed, as were her initial attempts to relate to others. Gradually she became more skilled both at knitting and at dealing with the outside world. Ultimately she even began to teach others how to knit and made gifts of her projects.

C. has been well for two years now. She knits less frequently, and no longer attends a day program, takes psychotropics, or sees me regularly. For the time being at least, she has managed to relocate within herself those supports that have helped her maintain a sense of well being. I like to think that in some small way learning to knit may have aided her recovery.

\title{
PSYCHOTHERAPY OR PSEUDOTHERAPY?
}

\author{
LAWSON R. WULSIN, M.D.
}

\author{
With thanks to Carl Salzman, M.D., for his help \\ in supervision and with this paper.
}

What is psychotherapy? I wish I knew. Thick books and long talks still leave me wondering. Hours of patients and almost as many hours of supervision leave the question hanging. I know what ECT is and how to give a good trial of amitryptiline, but I am never quite sure if what I am offering is true psychotherapy. Admittedly I am young and have only been wet for five years. But I have had one experience in my short time that put the question in perspective by putting it backwards, that is, what is not psychotherapy, or what is pseudotherapy?

This experience of pseudotherapy put me through the wringer, just as my first several borderline patients put me through the wringer. But the borderline experience came at me with banners snapping and darts flying and blaring kazoos. This experience with pseudotherapy, in contrast, snuck up on me and had me before I knew what it was or could call it a name. The embarrassment was at times fierce, but it set me on my toes. The next time someone like my man, and I hear there are lots like him out there, raps on my psychotherapeutic door, I shall be ready.

Dr. Wulsin is a fifth-year fellow in clinical research at Massachusetts Mental Health Center in Boston. 
Pseudotherapy, so far as I know, is not a term from the psychotherapy literature. I first ran into it, bluntly, in supervision where Dr. Carl Salzman was trying to show me what I was up to. The term as we used it in supervision and as I use it in this account refers to a semblance of psychotherapy, the motions without the substance, the talk without the genuine feeling, and ultimately long hours with little change. The suspicion of pseudotherapy is most likely to come from an overview of a series of sessions that miss their aim or seem aimless. The value of the concept is that it describes a form of resistance that hides in the disguise of the conventional dress of psychotherapy. The following account of a course of psychotherapy illustrates some features of this form of resistance.

I shall call him George Hucks, a 45-year-old man who acted 35 and liked to be called George and liked to call me Lawson. George came to the clinic of the state hospital after he failed a work-study project in the course of his training for a rehabilitation counseling degree. In the eight years since his divorce he had held numerous jobs which were unrelated to his original occupation as personnel manager in a small firm. Now he lived on welfare and had his parents finance his training as a counselor. His girlfriend was in therapy at the same clinic and he thought therapy would be good for his training as well as working on his dilemma of feeling torn between the "purple haze" of his creative life as a sculptor and the safety of returning to business. Could a career in counseling combine the two? How had he come to be on welfare? These were some of the early topics of the therapy.

In his attractive, pleasant manner George entertained me (it took us months to recognize it as such) with tales of his abandoning his business future, being wronged by his wife, attempts to peddle his art on the sidewalks, his impassioned affair with his stormy lover, and his thwarted attempts to find suitable work. He could talk with facility about insight and feelings and internal conflicts and books he was reading about the process of psychotherapy. What a contrast he provided me from my chronically ill hospitalized patients.

Then, after meeting for three months once a week, I forgot about our appointments three times within two months. There were other patients I might have preferred to forget. I did not know what led me to forget him. I felt torn between the apology I thought I owed him and the dictum of the patron saint of psychotherapy in this town, Elvin Semrad: investigate, investigate, investigate. George helped me out by telling me how he had also been forgotten in a recent job interview. Then another prospective employer rejected him half way through their first meeting and George asked, "Why don't they take me seriously?" I wondered aloud if he had succeeded in getting me not to take him seriously, in covertly giving me permission to forget about him.

At the same time my supervisor was badgering me with "What did he mean by that!" and "How can you listen to that garbage?" Garbage? That's not garbage, that's psychotherapy. "Maybe," he said, "but you don't know this guy, what he feels. He's got you guessing what he feels, he's not showing you. Difficult patient, not sure if he'll ever get into therapy." I was crushed. If we had not been doing therapy what had we been doing? I had not even realized he was a difficult patient.

Eventually, after some hesitation, I did what any up-to-date person does these 
days when having trouble with people. I turned to video. I asked George if he thought it might be helpful for us to see ourselves talking on videotape. He agreed but said he might tend to perform for the camera and not be his usual natural self. We taped one session and spent the next three reviewing it. We noticed that George's performance resembled his behavior with me in our regular sessions, and he felt badly that he performed without being aware of it. We noticed that his physical expressions of affect did not match the content of his words. When he talked of loneliness he raised ever so slightly his eyebrows and lifted the corners of his mouth. He could talk of anger with both hands relaxed in his lap. I wondered if these mixed messages made it hard for me and others to take his feelings seriously. Perhaps he confused his listeners, amiably putting them off with bits and gestures that did not fit into a whole impression. We also noticed that I frequently nodded or mumbled encouraging noises when I had no idea what he meant. In effect I coaxed him on with his confusions. Seeing this I felt small, naive, tricked, embarrassed. But there it was for both of us.

He had another way of putting me off that he and I had missed. He switched antecedents of his pronouns without giving any clue to me. What particularly got to me was his switching between me and his lover, so that for several minutes I would think his anger or affection were directed at me only to find out later that they had been directed at his lover, or vice versa.

Reviewing the tape undressed the process we had been calling psychotherapy, and George called a halt to the project after the third session. We taped another session several months later but only reviewed it once, again at his request. The cat was out but he was not sure he could or wanted to catch it. He was not sure he wanted to change.

We had been meeting twice a week for four months and soon after the second tape he decreased the frequency to once a week and got a part-time job as a counselor in a retirement home. Working his way off welfare was more important than talking about how he obscured communication, he said. In June (one year after we began) he shaved his beard for his parents who came to see him get his counseling degree. He showed up at our next appointment in a dapper suit and tie, a trim haircut, and a fine square jaw. "I've sold out," he announced with a smile full of whimsy and bitterness. "I want people to take me seriously."

My supervisor at this point could not bear my accounts of our hollow exchanges and begged me to simplify my contribution to one question, How do you feel? My supervisor was more concerned for George's well being than mine when he begged me to play the fool like that, but what could I do? He would not let me get away with anything more fancy than, How do you feel? To me it sounded as though I were saying, How do you feeeel? Under merciless pressure I persisted and eventually George stopped making fun of me and got the message that I had no idea most of the time how he was feeling. Then when occasionally genuine sadness or joy slipped out and I could feel it coming from him and it fit his words, the contrast stood out boldly. He learned to dare, if only briefly, to express genuine feeling that brought him closer to me, but he could not sustain either the feelings or the closeness. The experience for him, I think resembled peeking into a dim closet and seeing his own face.

For me those moments were thrilling, loaded with hope, uplifting counterparts to 
the aimless motions we had been through. Those moments confirmed both the shell of the man and the person inside. I was only sorry for their brevity.

We stopped meeting after two years for reasons incidental to changes in my training. I was sorry not to see it through to the end, though I imagined it would take some years. George chose not to continue in therapy with a new therapist. He talked for several months prior to our last meeting about terminations and beginnings and his feelings about them. He still talked about feelings rather than experiencing them on the spot with me. We may not have conducted good or true psychotherapy, but something good came of the effort. We learned the difference between connecting and obscuring, showing and telling, feeling and talking about feelings. We may have laid the groundwork for psychotherapy.

I would not tell about my shortcomings if I were not reassured by the good that came of our efforts, with a little help from my friendly supervisors. Effort and persistence overcame inexperience and taught us both (George and I) useful lessons. My supervisors tell me there are lots of people like George out there looking for psychotherapy. Big cities teem with therapists treating therapists of all kinds. We share the lingo, the habit of intellectualizing, the experience of therapy for training. The invitation to confuse roles is hard to resist. The difference between the motions and the genuine process of psychotherapy is at times hard to know but identifying this difference may provide, as it did in this case, the picture of the resistance and how it interferes with therapeutic progress. The ability to spot pseudotherapy may not define what psychotherapy is, but it helps.

\title{
THE IMPACT OF HYSTERECTOMY DURING ADOLESCENCE IN A WOMAN OF REPRODUCTIVE AGE
}

\author{
SUSAN K. BALL, M.D.
}

\section{INTRODUCTION}

There is extensive psychiatric literature on the psychological effects of hysterectomy on both pre-menopausal and post-menopausal women, but a careful search covering the last ten years and beyond reveals no references to the impact of hysterectomy during adolescence. There is also nothing on this subject in the gynecological literature of the last ten years. Obviously, the incidence of severe pathology necessitating hysterectomy is extremely rare. However, there can be little doubt that a procedure of such symbolic magnitude at an age when a young woman is

Dr. Ball is a fourth-year resident. 